\title{
$P$ Verster
}

\section{A CHURCH WITH THE POOR - LESSONS FROM SCRIPTURE AND FROM CONGREGATIONS IN INFORMAL SETTLEMENTS}

\begin{abstract}
The church has an essential role to play in communities riddled with poverty, disease, and despair. Communities in informal-settlement areas suffer a great deal. Churches in these communities are often small and have few means for alleviating poverty. In the Bible, the community of God is a community of love. Although there are instances of retribution in the Old Testament, there are clear instances where the community of God experiences the implications of love for one's neighbour. In the New Testament, the essence of the church is to be the community of love. Congregations in Mangaung's informal settlements bring a message of hope by being the community of love in their area. The church can become the true messenger of God's hope in informal areas.
\end{abstract}

\section{INTRODUCTION}

The presence of the church in informal settlements requires a new relationship with the poor. These churches are often poor, and have limited means. The physical structures are also often insignificant. People are living under dire circumstances in the informal settlements. The church's presence is of the utmost importance, but the way in which the church must be present should be researched.

\section{METHODOLOGY}

The qualitative research methodology used in this article is to, first, present the challenge of poverty facing people living in informal settlements in

Prof P Verster, Department Missiology, University of the Free State. E-mail: versterp@ufs.ac.za.

Acta Theologica

2012 Suppl 16: 70-88

DOI: http://dx.doi.org/10.4314/actat.v32i1S.5

ISSN 1015-8758

(C) UVIUFS

<http://www.uovs.ac.za/ActaTheologica> 
Africa, and especially in South Africa and in Mangaung in the Free State Province. This is done by perusing the literature on poverty. Secondly, a theologically Biblical and exegetical study of the community of faith in both the Old and the New Testaments is pursued. Thirdly, congregations in Bloemfontein's informal areas are studied. Conclusions are drawn and theological and missiological suggestions are made on how the church could become a church with the poor.

\section{RESEARCH QUESTIONS}

The main research questions are: How can the church become the church with the poor in the informal settlements, leading the fight against poverty while remaining true to its own character as church of Christ and as a community of love? With this in mind, what is the role of the church in Mangaung's informal settlements? How can the church, which is itself small and poor, become the living church with the poor?

\section{CHALLENGES OF THE POOR IN INFORMAL SETTLEMENTS}

\subsection{The city's attraction}

Informal settlements raise numerous questions concerning absolute poverty. Massive urbanisation in Africa has led to appalling poverty in the slums and informal settlements in and around big cities. The attractions of the big cities that cause this situation must be understood. People are of the opinion that they will experience a better life in the cities although they may still need an occupation and housing. The belief that city life will be better makes it attractive for people to flock to the cities. However, the reality is often very harsh and the dreams come to an abrupt end. Yet a new life is often started, even in the informal settlements, with a vision of new hope. Although previous governments in South Africa made an effort to keep people out of the cities, including Bloemfontein/Mangaung, the influx control laws had to be abolished in 1986 and people flocked to the cities. Since 2 February 1990, the poor have invaded land informally in the Mangaung area (Botes 1991:9). In addition, past injustices such as colonialism and "apartheid" and present crises such as political and economical malfunctioning have led to massive challenges for addressing poverty in informal settlements, while there is a substantial need for acceptable housing (see Oldfield \& Boulton 2007:1ff.) 
Concerning the challenges of informal areas and slums and the church's influence, Grigg (1992) explains that the frontiers of the churches' involvement moved to the destitute poor in many informal areas worldwide. Governments find it difficult to meet the challenges while the church also needs to address the serious problems of the urban poor (Grigg 1992:11). The lack of employment, in particular, remains an alltime high (see Mogoe 2002:89). Insufficient land leads to overcrowding in the informal areas (Mokomatsili 2005:1ff.). The serious challenge of the greater population growth which leads to poverty and lawlessness is also prevalent (Koekemoer 1999:2).

\subsection{The serious situation of the informal areas}

People who flock to the cities face serious challenges. Temporary living structures often provide insufficient shelter in changing weather conditions. Roads are not permanent. Schools and colleges are often situated far from the settlements. Governments are either ill-prepared to meet the challenges or unwilling to become involved. Disease is rife due to a severe lack of hospitals and clinics. Poverty is endemic. Rapid urbanisation leads to serious challenges concerning all aspects of life (Janse van Rensburg 2009:1ff.). Grigg (1992:42) refers to absolute poverty, when people's basic needs are insufficiently met, in absolute terms, among the third-world urban poor.

\subsection{The church in informal areas}

The church in informal areas also faces serious challenges. It often lacks structures to influence the community in a positive way. Krige (2008:156) explains that the church dynamic in Bloemfontein shows a lack of understanding for the challenges related to the fact that the church is a community involved with the poor. According to him, there is little understanding of a faith-based developmental and communityempowering approach. Mentorships and relationships, although key issues, are lacking; institutional capacity and good governance are lacking; spiritual and practical matters are separated, and woman are not utilised efficiently (Krige 2008:156-157). Although the body of Christ in poor areas often reaches out to the poor despite their own poverty, a lack of the means to become involved in a more structured way often plays a detrimental role. It is therefore important for the church to be a community of love despite its limited means. The solutions to poverty are not simple, but Grigg (1992:256-257) points out that the church may be able to transform the community among whom it is working by getting involved at grassroots level. 


\section{COMMUNITIES OF LOVE IN THE BIBLE}

\subsection{Israel as community of love in the Old Testament}

As God's people, Israel was a community of faith. Their faith in Yahweh led to a new relationship with their environment including themselves, their next of kin, and their neighbouring nations. The community was to be structured in such a way that God was fully honoured. Honouring God meant that they had to live holy lives. Their lives were outlined by God's commandments. Living with God also meant that people were to be honoured as created in the image of God. However, it must be mentioned that the harsh realities of life in the Old Testament also refer to dreadful wars and even genocides (Dozema 1996:7-10). This tension between being a community of love and a community of survival should be taken into account when reflecting on the role of the people of Israel in the Old Testament. The Old Testament fluctuates between the juxtaposed justice of holy war and love towards one's neighbour. Salhamer (2009:47-48) explains that the laws of the Old Testament were for the holiness of the people:

Above all, the message of the Pentateuch is centered in God's grace. Israel continually fell short of obedience to his will. God did not cast them off. God gave them more laws to guard them and to keep their lives pure and undefiled. The giving of the laws is thus shown to be an act of God's grace."

\subsubsection{The community of love in the Torah}

In the Torah, God's commandments clearly explain that the community of love should live in a relationship of love with God and fellow human beings. The community should be the community of love as it obeys God and reaches out to fellow human beings. Although God's love also calls for justice towards the people of Israel, the task to be the people of righteousness is clearly set out.

The Ten Commandments call for experiencing the wonder of God in the relationship with fellow human beings. The community of Israel should in all respects also be the community of love towards people. Kaiser (1990:420) explains the purpose of the law of God, namely to show man's awful sinfulness, the need of a mediator, and to show

...man how to live more abundantly by using the unchangeable perfections of the nature of God as revealed in moral law as guide. 
Acknowledging the glory of God, the people of God should live according to the emphasis placed on the other in the second part of the commandments. The commandments "You shall not steal" and "You shall not covet" clearly warn the people of Israel against the misuse of income. This should be read as calling people towards poverty alleviation. Wenham (2003:68) explains that obedience to the commandments leads to even greater intimacy with God. The holy community should also be a community in which the needs of the people are addressed. In many instances, aspects such as the Sabbath and Jubilee considered the poor and the labourer.

The way in which Exodus 22 and 23 are structured emphasises that the community needs to be the community of love (see 22:22-27 and 23:4-9). The love towards the poorest and most vulnerable, and towards widows and orphans should lead to justice for all. Even the enemy's ox or donkey must be taken back, for the justice of love is more important than retribution (see Kaiser 1990:439 ff.).

Leviticus 19:9-18 refers to the love for one's fellow human being in acknowledging his/her needs. Therefore, the harvest should not be taken in full by the farmers themselves, but the edges of the field should be left for the poor. In this regard, the commandment "Do not steal" finds new implications. The name of God is precious and, in honouring the deaf and the blind, it is again held in high esteem. In addition, the neighbour's life should not be endangered. Hate should not find a place in the heart. The community of faith should therefore always consider the needs and circumstances of one's fellow human being. This community should honour God in their love towards one another. Harris (1990:602-605) explains the different verses' significance for the spiritual life of the new community. In the New Testament, it is even linked to the life of the New People of God. The inner cohesion of the community meant that the underprivileged groups within it could not survive without the help of those who are better off (Gerstenberger 1996:267). Even the emulation of God's holiness had to lead to concern for those in need (Milgrow 1996:73).

Leviticus 25 emphasises that the Sabbath year and the year of Jubilee should be acknowledged by the community so that there is enough for the community. This can only be achieved in justice towards the land and one another (Wenham 2003:99). Weinfeld (2004:89) explains that the differences between the Priestly document and the Deuteronomist on ritual purity and practical purification emphasise the totality of life before God. In Deuteronomy 22:1-4 the main task is to help the person in need. Even conflict in a lawsuit does not exonerate a man from helping the other (Von Rad 1966:141). In verse 28 it is mentioned that all blessings come 
from God and not Baal. The community lives before God and finds solace in being a community of love receiving the blessings of God (Von Rad 1966:174).

Hartley (1992:323) writes:

Scripture reveals that love and holiness are intertwined. Holiness finds tangible expression in loving. Holiness purifies human love to be a dynamic interest in the well-being of another person. Each Israelite is enjoined to love one's neighbor, a person like oneself.

\subsubsection{The community of love in the Writings}

In the Writings, one finds a tension between the role of the people of God and war and justice, on the one hand, and the role of bringing justice to others, on the other. David fought dreadful wars but also showed mercy to many people. The story of David's mercy towards Mephibosheth is a clear example of this (2 Sam 9). Anderson (1989:143) writes:

The chapter must be seen in its historical setting where little or no mercy was shown to dethroned royal houses, and therefore David's attitude to Mephibosheth was clearly an act of kindness and conciliation since the latter had no bargaining power.

In 2 Sam 21, justice towards the Gibeonites where they are avenged is also important because the community of faith should show justice towards all. The wisdom of Israel also called for the community to be the community of love. The way in which God viewed the leaders of Israel emphasises the call to be a community of love.

The book of Ruth is an example of how the community of faith finds its essence in love towards one another.

What the scene must end with is something far more fitting, the clear evidence of Boaz' determination to care for these two widows as custom and generosity dictate (Campbell 1975:138).

\subsubsection{The community of love in the Prophets}

The Prophets called emphatically for justice and humanity from the people of God. The emphasis on the widows and the orphans as well as on the aliens also clearly explains the role of the people of God to be a community of love.

A good example is Isaiah $\mathbf{5 8}$ where the true fasting is explained as justice towards workers and the oppressed, the sharing of food with the 
hungry, and the provision of shelter for the wanderer. The Lord will hear the prayers of those who act in a loving way. The community of faith will also be established in the Lord if and when they break the yoke of the oppressed and spend themselves on behalf of the hungry. Watts (1987:277) writes:

The kind of worship God will choose and honor (vv. 5-14) is not ostentatious self-abnegation in fasting with much beating of breasts, but acts which overcome the problems (cf. Nehemiah's acts and programs in Neh 5). To please God, one should recognize wrongs, stop the ones doing wrong, and aid the victims (vv. 6-7).

\subsection{The church as community of love}

In the New Testament, the church is the community of love. Jesus as the Person of love calls upon his community of followers to be the community of love. This means that the church should also be the community of love for the poor.

\subsubsection{Community of love in the Synoptics}

The Sermon on the Mount is the essence of the church as the community of love. In Matthew, love is the essential commandment. In essence, the Sermon on the Mount is the commandment of the new community of love in Jesus Christ. Love your neighbour also means love your enemies. Bosch (1991:70) writes intriguingly:

The failure of Christians to live according to the standards of the Sermon on the Mount does not, however, absolve them from the challenge to do so. Particularly in our contemporary world of violence and counter-violence, of oppression from the right and the left, of the rich getting richer and the poor poorer, it is imperative for the church-in-mission to include the "superior justice" of the Sermon on the Mount (cf. Mt 5:20) in its missionary agenda.

Hagner (1993:101) explains the implications of the new community, the salt and light of the world, in Matthew:

This key pericope is virtually a programmatic or summarizing statement for the importance of living according to the righteousness of the newly arrived kingdom. It is first of all an affirmation of the unique identity of the disciples, an identity that depends on the gracious activity of their heavenly Father. They and they alone are the salt of the earth and the light of the world. 
The danger of failure looms large for the disciples if and when they are not light and salt. The people will throw them out not by persecution but because they themselves had failed (Betz 1995:160). The task of the church to be present as the community of love remains imminent. Thus, Christians who are not living for people other than themselves are worthless (Bruner 2004:189).

The travel narrative in Luke also mentions the task of the church to reach out to the poor in love, following Jesus' emphasis on the poor. The church cannot be church without following Jesus in His compassion for the poor. The community is called upon to explain and fulfil its duty in love (see Luke 10:25-37). Where the church reaches out to the most vulnerable, like the Good Samaritan, the church becomes the community of love.

\subsubsection{Community of love in the Johannine writings}

The Johannine community should be the community of love - as emphasised by the Johannine writings. This emphasis on love also emphatically explains the church's role. Although love for the fellow believer is emphasised, the reference is to Leviticus 19 and includes the community at large (Augerstein 1993:181). No evil should be done to those on the outside (Meeks 1996:324). The poor are not left out; in fact, the church's love for the world should also include the poor. The challenge for the Johannine community is to love according to the love of Jesus Christ, and because God is love, the community should also live out this love. Referring to John 17, Beasley-Murray (1987:307) writes:

The re-creation of believers as one Body in Christ should determine their common life. It is a principle which requires us to begin within the life of the local church, then extend outward, both to relations within communities of the same order as ourselves and to fellowships of Christians of other confessions.

\subsubsection{Community of love in the Pauline writings}

1 Cor 13 is the aspect of the community which clearly relates to one's fellow human being. This hymn of love was not written only from an eschatological perspective. It also arises out of Paul's trying experiences. An element of realism prevails, meaning that the community is drawn towards its yet to be obtained goal (Thiselton 2004:118). From this aspect of faith, the community of love reaches out to the poor. Mare (1980:267) shows how this beautiful chapter speaks of the superiority and necessity of love and that gifts are nothing without love: "Love is the most excellent way for a Christian to use his spiritual gifts." In 1 Cor 13 the emphasis on 
the acquittal of the one that wronged you should also be viewed in the light of forgiveness and restitution. Love clearly does not seek its own (Conzelmann 1975:231).

\section{THE CHURCH IN INFORMAL SETTLEMENTS}

\subsection{Guidelines for the church as community of love}

From the perspective of a missiologist, Bosch (1991:368ff.) defines the church in its relation towards others. He (Bosch 1991:375) explains that the church was regarded as the church for the other but that this notion was criticised. The church does not exist only for the other. The church is the Church of Christ. Therefore the church cannot be the church of the other (poor) only. The church is the total community of God in fullness of life before God. Bosch (1991:372) suggests that the church be recognised as the church with the other, the church with the poor, as it communicates the whole of life with God with the people among whom they are living. Bosch (1991:389) writes:

We now recognize that the church is both a theological and a sociological entity, an inseparable union of the divine and the dusty. Looking at itself through the eyes of the world, the church realizes that it is disreputable and shabby, susceptible to all human frailties; looking at itself through the eyes of the believers, it perceives itself as a mystery, as the incorruptible body of Christ on earth.

The missiologist Wright (2006:191ff.) also explains how the community of faith is the elect people who are called to be a blessing for others. God's particular people are called and chosen for all (Wright 2006:222). The message of this elect people is both universal and particular (Wright 2006:243-264). The election is the call for the nations to be saved and therefore election is never a means to itself (Wright 2006:264).

According to Moltmann (1977:289ff.), from the perspective of liberation, the church is the church in the power of the Spirit. The church is the Messianic people who live the life of the community of the Spirit. In this community, the church in service of various ministries presupposes the general service of the kingdom of God. Moltmann (1977:300-301) emphasises the aspect of the community's task which lies in the calling of believers through Christ of the kingdom of God through the power of the Holy Spirit. He (Moltmann 1977:301) mentions that it is the "priestly people, which intercedes for others and bears witness before the world to 
the liberating representation of Christ." The new creation is possible in the church as the new community in the Power of the Holy Spirit.

Küng's (1978:107ff.) Roman Catholic view emphasises that the fundamental structure of the church is the church as people of God, the church as creation of the Spirit, and the church as the body of Christ. In this regard, the church, i.e. the disciples of Jesus, is the church that serves. Küng (1978:392) writes:

\begin{abstract}
It is not law or power, knowledge or dignity but service which is the basis of discipleship. The model for the disciples in their following of Christ is therefore not the secular ruler and not the learned scribe, nor even the priest who stands above his people ... the only valid model is that of the man who serves at the table...
\end{abstract}

From the Roman Catholic perspective, Bevans and Schroeder (2006:391) explain the importance of reconciliation in the church as community of God. They emphasise that there are different levels of reconciliation. First, there is the personal reconciliation with God and the personal reconciliation of people among themselves on a personal level such as between husband and wife. Secondly, the cultural reconciliation calls for the difficult but essential aspect of transcultural reaching out to one another. Thirdly, there is the political reconciliation. The last is reconciliation within the church itself where churches need to accept that they must also reach out to others (Bevans \& Schroeder 2006:392). It should always be borne in mind that the ministry of reconciliation should be accepted as emanating from God. God's amazing grace brings about true reconciliation and heals brokenness (Bevans \& Schroeder 2006:393).

It should be emphasised that the church is God's new community, a community reaching out to the world in love, being the community of love itself.

\title{
6.1 Congregations with the poor in the community in Mangaung
}

In group discussions, the role of the church as community of faith in Mangaung's informal settlements was established. The discussion focused on the situation of the community and the role of the church to be a community of faith within such a community. First, the discussion established the circumstances in which people live. Secondly, it focused on the needs of the congregation. Thirdly, it emphasised the contribution of the congregation and, lastly, the support needed. 


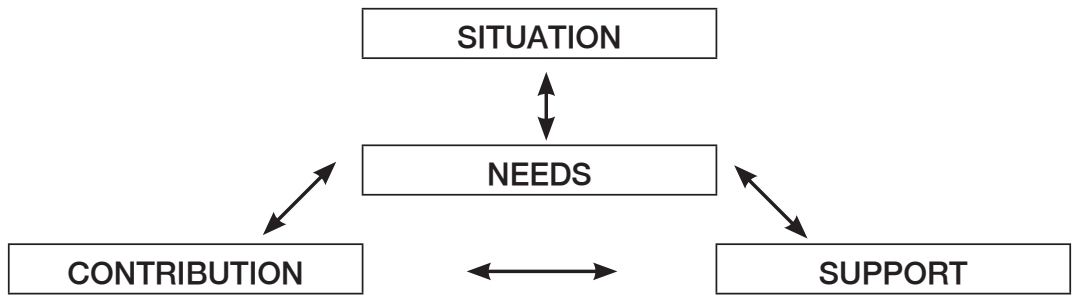

\subsubsection{The African First Apostolic Church}

\section{i. Situation}

Situated in the informal settlement area, the church is aware of the severe poverty, lack of jobs, and diseases in the community.

\section{ii. Needs}

The church needs a site that is registered in its name, i.e. they need to know that there is a place where their services can be conducted. They also need to have a church building so that they can take in street kids and other people in need and try to accommodate them. The sites are available but the problem is finance. They thus need financial assistance in order to buy those sites.

\section{iii. Contribution}

Being the community of faith, they want to reach out to the community in a practical way by opening a crèche to help generate profit for those in need. Another way is to start a business where they sell bricks to help the community but also to generate funds. The problem is that they need to buy coal for baking the bricks. However, as the coal must be fetched from the Eastern Cape, they are in need of transport. They need the help from someone who can meet them halfway in order to change the situation.

\section{iv. Expected support}

They also need a site from the government to start a farming project so that they can plant and sell vegetables. The money thus obtained will help those in need. A member of the congregation put it as follows: "If we can get training in such things as how to help those who are diagnosed with HIV/AIDS and pregnancy and to help the pensioners as the church." 


\subsubsection{The First King church}

\section{i. Situation}

The church is also aware of the severe needs of a community without much support.

ii. Needs

They also emphasised the need for a site that belongs to them so that they can help the unemployed and the sick. The church is already involved in collecting money to help those in need. The problem is that the church is financially poor.

iii. Contribution

They are also willing to do many things, but the church is not in a good state of repair. Their church building consists of a shack, and if they could build a church building, they believe that the situation among the poor can change.

iv. Expected support

If they can obtain sponsors, this would provide them with the opportunity to start projects. In particular, they need a sponsor for the youth choir which would allow them to hold concerts, thereby obtaining funds to assist those in need. The main problem is finance.

\subsubsection{Moving gospel ministry}

i. Situation

The community needs help on various levels, e.g. education, medical services, jobs, food. Some people in their area are suffering a great deal and they really need help.

ii. Needs

The challenge is, once again, of a financial nature in that they find it difficult to pay for their church site. At this stage, they manage to pay half the amount which is R16 000.00. They are trying their best to help those in need. They want to fence off their yard so that they can accommodate those in need.

iii. Contribution

There is a need to start different projects such as a soup kitchen, sharing with the poor by doing charity work, and providing clothes, food, etc. They also need to train the youth in order to prevent teenage pregnancies. 
iv. Expected support

If the churches can cooperate, they will be able to assist those in need. As church leaders, they should have frequent meetings to discuss these issues.

\subsubsection{Dutch Reformed Church in Africa: Bloemfontein-West i. Situation}

The majority of the people in this congregation are poor and unemployed. Youth pregnancies and crime prevail. The problems start at home; some parents are acting recklessly instead of taking care of the family. Drinking alcohol has an impact in this area, causing people to act irresponsibly. A lack of skills, such as how to take care of one's family and what to do when faced with challenges, is prevalent. This congregation does not have the technology to attract the youth and their parents to church. Crime also plays a part in the community as people are illiterate and unemployed. Being poor, many young people start out by becoming prostitutes, selling their bodies in order to get money. Ultimately, these young people fall pregnant or become infected with HIV/AIDS.

ii. Needs

The church is poor and is therefore unable to meet all the needs of the community.

iii. Contribution

The church is called to be a community of faith. Training courses will help a great deal in combating the problem. Projects are needed to solve the problem of unemployment.

iv. Expected support

A youth centre would help to take the youth off the streets, and could assist in the fight against drugs. The congregation also needs skills for reaching out to the youth in the community.

\section{THE LIVING CHURCH IN THE COMMUNITIES}

In serving the community, the church should understand the community, be sincere in its commitment, and build a relationship of trust (Mattessich \& Monsey 1997:45-47). Although many churches are in need of sites and buildings in order to reach out to the community, they serve the community by being present in the informal settlements. Much can be learned from the 
churches. The church must not become a huge structure to overpower the situation. The church must not seek power. The church must be present in humility. The love among the members must be the glue of the community of faith but also the aspect calling people to faith. Barret (1985:101) writes:

And I find myself wondering whether the church in any age has taken the New Testament really seriously - seriously enough; whether we have learnt to balance our peripherality against our centrality; whether we believe that every member of the church is in some sense a minister and in every sense a priest, so that we do in honour prefer one another, encourage one another to find each his own ministry, and follow each his own calling for the good of all; whether every meal we take, especially every meal the church takes together, is transformed by the fact of the real presence; whether we honestly believe that it is better to give than to receive, to serve than to be served; whether we believe in the justifying gracious initiative of God...

\section{A few practical suggestions can be made:}

- Being the community of love, the church should be present among the poor with compassion in the way that it feeds those who are immediately without food and cares for those who are ill and without immediate help.

- Being the community of faith, the church should establish living faith in the community. Faith generates hope and only through hope can a new situation be realised.

- Severely malnourished children die daily in South Africa (Thom 2010:7). The church should be actively involved in changing the situation by helping households in their areas and by tending to their immediate needs.

- Approximately $70 \%$ of young children in rural and informal settlements do not have access to important services, including basic earlychildhood learning, education, social security grants, birth certificates, and regular attendance to clinics, according to a report in Ons Stad (18 June 2009:14). The church as a community of faith can be instrumental in establishing networks of help for the young children.

- The church can get involved in helping to advance education and reading programmes, in particular (see Van der Westhuizen's [2009:167168] reference to the challenges at schools in informal areas). 
- The church can care for orphaned children of whom there are no less than 3.95 million in South Africa and of whom 1.4 million are infected with the HIV/Aids virus, according to the South African Institute of Race Relations (Kock 2011:3), by providing family structures (see Mwaura [2005:39] who refers to widespread informal care).

- The church can help the community to take responsibility for their own environment (Shwababa 2004:63).

Majawa (1998:261) writes:

It (the church) needs to intensify its efforts in educating people politically so that they may become mature citizens who: know their rights as well as obligations, protect the environment, work hard to eradicate ignorance, poverty and disease, etc. Alleviation of poverty and suffering in Africa has to be at the centre of the Church's pastoral planning.

\section{CONCLUSION}

The challenges of the poor in informal settlements call for an approach of mediating love by the church. The church is also the church under the cross. Therefore the church reaches out to desperate people who are also living under the cross to allow them to experience the love of Him who, by dying on the cross, has opened up a new life of the new people before God. The cross is not the end. The cross is followed by the resurrection. As people of God, the love of the resurrected One is radically proclaimed to the poorest of the poor.

\section{BIBLIOGRAPHY}

Anderson, A.A.

1989. 2 Samuel. Word Biblical Commentary. Vol. 11. Dallas: Word Books.

Augerstein, J.

1993. Das Liebesgebot im Johannesevangelium und in den Johannesbriefen. Stuttgart: Kohlhammer.

BARRET, C.K. 1985. Church, ministry, and sacraments in the New Testament. Exeter: Paternoster.

Beasley-Murray, G.R. 1987. John. Word Biblical Commentary. Vol. 36. Waco: Word Books. 


\section{BETZ, H.D.}

1995. The Sermon on the Mount. Minneapolis: Fortress Press.

\section{Bevans, S.B. \& Schroeder, R.P.} 2006. Constants in context: $A$ theology of mission for today. Maryknoll: Orbis.

Bosch, D.

1991. Transforming mission: Paradigm shifts in theology of mission. Maryknoll: Orbis.

BOTES, L. 1991. Informal settlements in Bloemfontein: A study of migration patterns, socio-economic profile, living conditions and future housing expectations. Johannesburg: Urban Foundation.

BRUNER, F.D. 2004. Matthew: A commentary, Vol 1. The Christbook. Matt 1-12. Grand Rapids: Eerdmans.

Campbell, E.F. (JR.) 1975. Ruth. (The Anchor Bible). New York: Doubleday.

Conzelmann, $\mathrm{H}$. 1975. 1 Corinthians: A commentary on the first epistle to the Corinthians. (Translated by J.W. Leitch). Philadelphia: Fortress.

Dozema, N.T.B.

1996. God at war: Power in the Exodus tradition. New York: Oxford.

Gerstenberger, E.S.

1996. Leviticus: A commentary. (Translated by D.W. Stott). Louisville. Westminster John Knox.

GRIGG, V. 1992. Cry of the urban poor. Monrovia: MARC.

HAGNER, D.A.

1993. Matthew 1-13. Word Biblical Commentary. Vol. 33A. Dallas: Word Books. HARRIS, R.L. 1990. Leviticus. The Expositor's Bible Commentary. Vol 2 (Genesis - Numbers). Grand Rapids: Zondervan.

HARTLEY, J.E. 1992. Leviticus. Word Biblical Commentary. Vol. 4. Dallas: Word Books.

Janse van Rensburg, J. 2009. Spatial planning and the management of sprawl by applying an urban edge strategy in small towns: The case of Bitou. Unpublished Masters dissertation. UFS: Bloemfontein. 
KAISER, W.C. (JR.). 1990. Exodus. The Expositor's Bible Commentary. Vol 2 (Genesis - Numbers). Grand Rapids: Zondervan.

Коск, O.

2011. South Africans must change habits. Citizen. 7 Apr 2011 p. 3.

KoeKEMOER, J. 1999. The importance of urban planning in the development of a low cost housing scheme. Unpublished final project. BSC(QS). UFS: Bloemfontein.

KRIGE, S.

2008. Transforming Christian churches into community-based resource centres, with reference to Bloemfontein: In: L. Marais \& G. Visser (Eds.) Spatialities of urban change: Selected themes from Bloemfontein at the beginning of the $21^{\text {st }}$ century (Stellenbosch: Sun Press), pp. 155-181.

KüNG, H.

1978. The Church. (Translated by R. \& R. Ockenden.) London: Search Press.

MajaWA, C.

1998. The Church's prophetic role in the struggle against poverty in Africa. African Ecclesial Review 40(5-6):258-270.

MARE, W.H. 1976/1980. 1 Corinthians. The Expositor's Bible Commentary. Vol 10 (RomansGalatians). Grand Rapids: Zondervan.

Mattessich, P. \& Monsey, B.

1997. Community building: What makes it work. A review of factors influencing successful community building. St. Paul: Wilder Foundation.

Meeks, W.A.

1996. The Ethics of the fourth Evangelist. In: R.A. Culpepper \& C.C. Black (eds.) Exploring the Gospel of John (in honour of D. Moody Smith). (Louisville: Westminister John Knox), pp. 317-326.

MILGROW, J.

1996. The changing concept of holiness in the Pentateuchal codes with emphasis on Leviticus. In: J.F.A. Sawyer (ed.). Reading Leviticus - A conversation with Mary Douglas: JSOT Suppl. 227. Sheffield Academic: 65-75.

Mogoe, M.E.

2002. The impact of HIVIAids on housing in Mangaung with planning guidelines for the future. Unpublished Masters dissertation. UFS: Bloemfontein.

МокомATSILI,T.P.

2005. Relationship between the town planning scheme and the spatial development framework in the Free State. Unpublished Masters dissertation. UFS: Bloemfontein. 
Moltmann, J.

1977. The church in the power of the Spirit. (Translated by M. Kohl) London: SCM.

Mwaura, S.K.

2005. Community-based project for orphans and vulnerable children in Mamelodi Township. Unpublished Script (Developmental Studies). UFS: Bloemfontein.

Oldfield, S. \& Boulton, J.

2007. Crowded houses, gendered spaces and generational differences: The inter-relationship between housing politics and household dynamics in New Crossroads, Cape Town. Roma: National University of Lesotho.

ONS STAD

2009. DEDI Celebrates 10 years of uplifting poor. 18 June p. 14.

SALHAMER, J.H.

2009. The meaning of the Pentateuch: Revelation, composition and interpretation. Downers Grove: IVP-Academic.

ShWABABA, S.Z.

2004. Attitudes, causes, effects and possible solutions of littering in open spaces of Mlungisi Township. Unpublished Masters dissertation in Environmental Management. UFS: Bloemfontein.

Tном, A.

2010. Hunger eats at SA children. Witness 11 Dec 2010 p. 7.

Thiselton, A.C.

2004. Realized eschatology at Corinth. In: E. Adams \& D.G. Horrell (eds.) Christianity at Corinth: The quest for the Pauline church (Louisville: Westminister John Knox), pp. 107-118.

VAN DER Westhuizen J.S.

2009. The development of reading at a township school: An action research study. Unpublished Masters dissertation. UFS: Bloemfontein.

Von RaD, G.

1966. Deuteronomy. London: SCM.

WATTS, J.D.W.

1987. Isaiah 34-66. Word Biblical Commentary. Vol. 25. Waco: Word Books.

WeINFELD, M.

2004. The place of the laws in the religion of ancient Israel. Leiden: Brill.

Wenham, G.J.

2003. Exploring the Old Testament: A guide to the Pentateuch: O.T. Vol 1. Downers Grove: IVP. 
WRIGHT, C.J.H.

2006. The mission of God: Unlocking the Bible's grant narrative. Nottingham: InterVarsity.

INTERVIEWS HeLd IN PHASE 7 INFORMAL SETtLement IN MANGAUNG 2009-2011: 2009. The African First Apostolic church

2009 The First King church 2009 The moving gospel ministry

2011 The Dutch Reformed Church in Africa: Bloemfontein-West

Keywords

Poor

Informal settlements

Scripture

Church

\section{Sleutelwoorde}

Armmoede

Informele behuising

Skrif

Kerk 